\title{
Determinan Online Purchasing Decisions and Its Impact on Online Re- Purchase in Tangerang Selatan and Jakarta
}

\author{
Herry Krisnandi \\ \{herry.krisnandi@ civitas.unas.ac.id\}, Nasional University, Jakarta, Indonesia \\ Rahayu Lestari \\ \{rahayu.lestari@civitas.unas.ac.id\}, Nasional University, Jakarta, Indonesia
}

\section{Rahman Laba}

\{jeneponto2000@yahoo.com\}, Faculty of Economics and Business, Hasanuddin University, Makassar, Indonesia.

\author{
Mahlia Muis \\ \{mahliamuis@gmail.com\}, Faculty of Economics and Business, Hasanuddin University, Makassar, \\ Indonesia. \\ Maat Pono \\ \{maatpono@yahoo.com\}, Faculty of Economics and Business, Hasanuddin University, Makassar, \\ Indonesia.
}

\begin{abstract}
Purpose of this research discuss issues concerning to the purchase of repeated online done consumers/customers to the online. Respondents in this research was the consumers who makes purchase of products online in the areas surrounding the South Tangerang - Jakarta pass judgment in the form of answer a list of questionnaire researchers. Technique the analysis used to answer hypothesis in this research uses Structural Equation Modeling; should be conducted by Software Amos 22.00. Sample of the used as many as 200 respondents who being in the region South Tangerang-Jakarta. The results provide a summary associated with the decision to purchase the online there one variable product innovations have no influence, while two other variables affecting the promotion and trust. Online price relating to the purchase of online birthday there is one variable promotion the price does not affect, while two other variables affect. product innovations and trust.
\end{abstract}

Keywords:

Product Innovations Price Online Promotion, Trust, Decision To Purchase Online and Repurchases Online.

Article Received: 18 October 2020, Revised: 3 November 2020, Accepted: 24 December 2020

\section{Introduction}

\subsection{Background}

In 2015 Deloitte announced the good news for Indonesia. The second largest accountant company in the world that discusses the potential of online Small Medium Enterprise can increase economic growth in Indonesia. No half-hearted Indonesian economic growth is predicted to reach $7 \%$ if the current development of Online Small Medium Enterpriseis needed. Means there is an additional economic growth of $2 \%$.

In Indonesia itself, the amount of internet users has reached 132 million people. This reflects that more than half of Indonesia's population has an access to the internet. The same report even explained that $60 \%$ of the internet users can access the internet through smartphone. Besides the continues increase in internet access, the duration of internet usage in the world also keep increase significantly. In this case, Wearesocial reported that the average internet usage in the world is six hours per day through various devices (https://www.goodnewsfromindonesia.id, 2018). An interview conducted by Deloitte on 437 Indonesian Small Medium Enterpriseusing online and face-to-face panels. The Small Medium 
Enterpriseinterviewed came from 6 major cities in Indonesia. These cities include Jakarta, Surabaya, Bandung, Semarang and Makassar. And it is proven that $3 / 4$ Indonesian Small Medium Enterpriseare already using online marketing. As much as $36 \%$ of Indonesian Small Medium Enterprisestill only use offline marketing. While $37 \%$ of other Indonesian Small Medium Enterpriseuse online marketing, although its use is still in the one-way marketing stage. For Small Medium Enterprisewho already use advanced online marketing such as social media and chat, the number is only $18 \%$. And the rest which is less than $9 \%$ of Indonesian Small Medium Enterprise that make the most of online marketing such as ECommerce (http://goukm.id/ukm-online, 2018).

Technology has developed increasingly so business have more opportunities to grow and develop quickly. The growth of e-commerce is also driven by the rapid technology adoption led by the increasing use of devices such as smart phones and tablets, and access to the internet through broadband, 3G, 4G, etc. [1]. Customers usually rely on the internet to purchase variety products and services online. It effectively can become the tool that helps customers in comparing prices, product features, and after sale services facilities which they will receive after the online purchase of the product made. In this case, E-commerce provides an advantage for the companies because it can fasilitate them to be easily in touch with the actual and potential customers [2].

Review rating of goods is the initial attitude of consumer, which is evaluated by the consumer on goods. The reviews systems of Business to Consumer and Consumer to Consumer are slightly different. In this case, Consumer to Consumer review system involves positive, moderate, and negative reviews, while Business to Consumer doesn't have this option. In this study, we analyze how the quantity of these star ratings on Consumer to Consumer website (Taobao) can affect the consumer purchase behavior. Some study show that the quantity of positive reviews have a significant role on the consumer decision making, while the quantity of moderate reviews have no impact and the negative reviews have negative impact instead on consumers buying behavior. [2]

\subsection{Theoretical Framework}

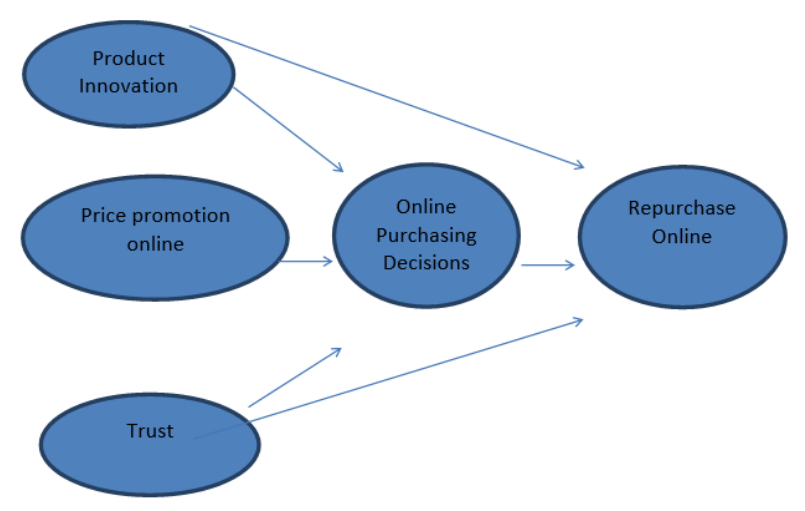

Fig.1. Research Concept

\subsection{Problem}

Based on the background that has been described previously, the problems in this study are as follows:

1. How much influence the product innovation has on online purchasing decisions?

2. How much influence the online price promotion has on online purchasing decisions?

3. How much influence does trust have on online purchasing decisions?

4. How much influence does product innovation have on repurchases?

5. How big is the effect of online price promotions on repeat purchases?

6. How much influence does trust have on repurchases?

7. How big is the influence of online purchasing decisions on purchasing again?

\subsection{Hypothesis}

The hypothesis in this study, among others :

$\mathrm{H}_{1}=$ There is a positive influence of product innovation on online purchasing decisions

$\mathrm{H}_{2}=$ There is a positive effect of online price promotions on online purchasing decisions

$\mathrm{H}_{3}=$ There is a positive influence of trust on online purchasing decisions 
$\mathrm{H}_{4}=$ Terdapat pengaruh positif inovasi produk terhadap pembelian ulang

$\mathrm{H}_{5}=$ There is a positive effect of product innovation on repurchases

$\mathrm{H}_{6}=$ There is a positive influence of trust on repurchases

$\mathrm{H}_{7}=$ There is a positive influence on online purchasing decisions on repeat purchases

\section{LITERATURE REVIEW}

\subsection{UMKM}

Medium Business is a productive economic business that stands independently and carried out by the individuals or business entities that are not subsidiaries or branch companies which owned, controlled or a part of other small or large business, either directly or indirectly with a net worth or yield annual sales as stipulated in the Regional Regulation.

\subsection{Online Marketing}

Online channels are channels that can be reached by someone through a computer and modem. Modems connect computers to telephone lines so that computers can reach a variety of online information services.

Users can send e-mails, exchange ideas, shop for goods, and access news, food recipes, art information, and business information. The internet itself is free, although users must pay for commercial services to connect to it.

\subsection{Product Innovation}

Innovation is a way to continue to build and develop organizations that can be achieved through the introduction of new technologies, new applications in the form of products and services, the development of new markets, and introducing new forms of organization. Innovations can be divided into two parts: first, process innovation involves the development of new management and organizational practices; second, product innovation involves the application of knowledge for the development of tangible new products and new services [4].

\subsection{Online Promotion}

Promotional activities as a means of communication between producers and consumers to introduce products, both types, colors, shapes and prices, as well as the quality of products offered or produced by the company. Promotion [6], is information for the act of exchange and purchase or one-way information tool for someone.

Basically promotion is an effort in the field of information, appeal, persuasion and communication and it can be said that promotion is a two-way exchange of information between the parties involved. For companies that produce products or services, interactions that occur between companies and consumers are only realized through the communication process. Online promotion is the process of activities carried out by parties (companies) in offering products or services that are introduced or advertised through online media (internet), so there are no face-to-face meetings between buyers and sellers.

\subsection{Online Prices}

Priceis the amount of money or goods needed to obtain a combination of other goods accompanied by the provision of services. According [7], indicators used to measure prices include :

1. Prices that match benefits

2. Perception of prices and benefits

3. The price of goods is affordable

4. Price competition

5. Appropriate price with quality

\subsection{Trust}

So it can be stated that trust is a certain party's confidence in others in conducting a transaction where the party they believe will fulfill what is promised and as expected. In an online shopping system, when a consumer wants to decide to buy a product online or shop online, there must be a doubt that a risk will be accepted by the consumer. Therefore trust is very important in 
electronic commerce since the internet business is believed by consumers.

Defining trust as the person most often guarded is about their privacy, that is, when they don't have trust in others. In this research, trust is interpreted as the online vendor can give consumers confidence about their privacy [9]. Indicator :

1. Security of transactions

2. Websites can protect privacy

3. Good service online vendors

4. Online vendors can be trusted

5. Trusted online shop

\subsection{Online Purchasing Decisions}

Purchase decisions are activities of individuals who are directly involved in making decisions to make a purchase of a product offered by the seller. Understanding purchasing decisions [10]. Consumer behavior is a complex psychological response, which arises in the form of unique individual behavior that is directly involved in the business of obtaining and using products, and determines the decision making process in purchasing products, including in repurchasing [12].

Then every company can try to simplify the decision making that will be done by consumers. The purchase decision indicators [13] that is :

1. Perfectionists (quality conscious consumers)

2. Be aware of the brand and price

3. Awareness of new models

4. Consumer habits

\subsection{Online Repurchase}

Repurchase intention is a positive attitude of consumers towards e-retailer that will generate repeat purchases (repeat buying behavior). Zhou et.al. (2009) and Kim et al, (2012), repurchase intention is that consumers are interested in making a purchase by using online shopping, consumer online shopping will be revisited in the future and consumers are interested in to recommend online shopping because they also use online shopping [14]

Define online repurchase intention as a customer's desire to make a repeat purchase in the future. In this research, online repurchase intention is defined as customers wanting to buy back online products. The following indicators [15] :

1. Plan to buy the same product

2. Plan to try other products

3. Plan to buy more of the same product or other products

\section{RESEARCH METHODS}

\subsection{Object of research}

The object of research in this study is online repurchase and purchasing decisions that are influenced by product innovation, online price promotions and trust.

\subsection{Method of collecting data}

The sample collection technique used in this study is the purposive sampling method, namely the community as consumers who use online applications in conducting product purchase transactions through online applications located in the South Tangerang-Banten and Jakarta regions.

\subsection{Data Types and Sources}

Types and sources of data in this study are: primary data sources that are obtained through questionnaires.

\subsection{Population and Sampling Techniques}

Sampling in this study was carried out using certain considerations [16], finding that for the SEM model, the appropriate sample size was between 100-200. If the sample size is too large, for example 400, then the method becomes "very sensitive" so that it is difficult to get good goodness of fit measurements, stating that the sample size guidelines depend on the number of indicators times 5 to 10 .

\subsection{Data Analysis Method}

Data analysis, conducted for the purpose of: presenting empirical findings in the form of descriptive statistical data that explains the characteristics of respondents, especially in relation to the research variables used in 
hypothesis testing and inferential statistical analysis used to test the proposed research hypotheses and on that basis a conclusion is drawn. Statistical descriptive analysis with SPSS release 23.00 .

This research was conducted in 4 stages, namely a preliminary survey, preparation of cake, data collection, and analysis. Analysis of the Structural Equation Modeling method was carried out with Amos 22.00 software. The measured variables are product innovation, online price promotion, trust, online purchasing decisions, and online repurchases.

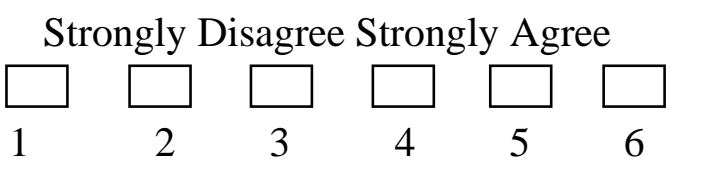

Respondents only need to check (check list) or check the statement box that is considered most in line with their expectations. Before analyzing the data, the validity and reliability tests are first performed. Validity test is intended to test research instruments. In this study, the validity of the instrument was tested on 30 respondents. Measured variables are said to be valid if the product moment correlation value: $r$ yield $>r$ table (critical value) matches the number of samples used. Reliability testing was carried out with Alpha Cronbach. Instrument testing is a tool that meets academic requirements so that it can be used as a tool to measure an object of measurement or collect data about a research

* Respondent Description

a. Age of Respondents
Structural equation modeling is a tiered causal model that includes two main types of variables namely latent variables and observation variables. The analysis technique used to answer the hypotheses in this study uses the Structural Equation Modeling which is processed with the help of Amos 22.00 software.

\subsection{Materials / Tools, Research Instruments}

1. The scale used in the preparation of the questionnaire is a rating scale from 1 to 10 to obtain data that are interval or intervally scaled Ferdinand data $(2014 ; 206)$.

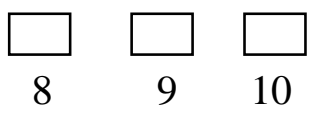

variable. Validity is the ability of a measuring tool to measure what should be measured. Reliability is how consistency (constancy in terms of accuracy) of the measuring instrument when used in the measurement process.

\section{RESULTS AND DISCUSSION}

\subsection{Research Result}

\subsubsection{Description of Research Object}

The identity of respondents in this study will be divided into three groups, namely the identity of respondents based on age, gender, age, and frequency of online purchase transactions in one month.

Table 1. Age of Respondents

\begin{tabular}{|c|c|c|c|c|c|}
\hline & & $\begin{array}{c}\text { Frequenc } \\
y\end{array}$ & Percent & $\begin{array}{c}\text { Valid } \\
\text { Percent }\end{array}$ & $\begin{array}{l}\text { Cumulative } \\
\text { Percent }\end{array}$ \\
\hline \multirow[t]{4}{*}{ Valid } & $20-24$ & 90 & 45.0 & 45.0 & 45.0 \\
\hline & $25-30$ & 76 & 38.0 & 38.0 & 83.0 \\
\hline & $>30$ & 34 & 17.0 & 17.0 & 100.0 \\
\hline & Total & 200 & 100.0 & 100.0 & \\
\hline
\end{tabular}

Source : Data processed by SPSS 23.00, 2019. 
Based on table 1 above, the highest number of respondents with a range of ages 20-24 years amounted to 90 people (45\%), aged 25-30 years totaling 76 people $(38 \%)$, aged $>30$ years totaling 34 people $(17 \%)$. This shows that the majority of respondents who make online transactions related to purchasing decisions and repurchase online have an age of 20-24 years or $45 \%$. This means that the majority who make online purchases have a age of 20-24 years.

b. Gender

Table 2. Gender

\begin{tabular}{rlrrrr}
\hline & & Frequenc & Percent & Valid & Cumulativ \\
Percent & e Percent \\
Valid & Man & 62 & 31.0 & 31.0 & 31.0 \\
& Woman & 138 & 69.0 & 69.0 & 100.0 \\
& Total & 200 & 100.0 & 100.0 & \\
\hline
\end{tabular}

Source : Data processedby SPSS 23.00, 2019.

Based on table 2, the above shows that the highest number of respondents is female with a total of 138 people (69\%), while the male gender is 62 people (31\%). This shows that the majority of respondents who make online transactions are female.

\subsubsection{Frequency of Online Purchases in One Month}

Table 3. Frequency of online purchases in a month

\begin{tabular}{|c|c|c|c|c|c|}
\hline \multirow{5}{*}{ Valid } & & $\begin{array}{c}\text { Frequenc } \\
\mathrm{y}\end{array}$ & Percent & $\begin{array}{c}\text { Valid } \\
\text { Percent }\end{array}$ & $\begin{array}{c}\text { Cumulative } \\
\text { Percent }\end{array}$ \\
\hline & 1 & 130 & 65.0 & 65.0 & 65.0 \\
\hline & 2 & 55 & 27.5 & 27.5 & 92.5 \\
\hline & 3 & 15 & 7.5 & 7.5 & 100.0 \\
\hline & Total & 200 & 100.0 & 100.0 & \\
\hline
\end{tabular}

Source : Data processedby SPSS 23.00, 2019.

Based on table 3, the above shows that the highest number of respondents' online purchases in one month is 130 people $(65 \%)$. Transactions in one month are twice as many as 55 people $(27.5 \%)$ and three times as many as 15 people $(7.5 \%)$.

* Data Quality Test (Instrument Test)

\subsubsection{Test Validity}

Table 4. Item-Total Statistics

\begin{tabular}{ccccc}
\hline & Scale & Scale & Correcte & Cronbach's \\
Mean if & Variance & d Item- & Alpha if \\
& Item & if Item & Total & Item \\
& Deleted & Deleted & Correlati & Deleted \\
& & & on & \\
Technical Inovation & 142.0667 & 839.030 & .616 & .956 \\
\hline
\end{tabular}




\begin{tabular}{|c|c|c|c|c|}
\hline Design change & 142.2000 & 815.890 & .804 & .954 \\
\hline Creativity & 141.4667 & 852.947 & .467 & .958 \\
\hline Distribution change & 140.8000 & 876.924 & .329 & .959 \\
\hline $\begin{array}{l}\text { Pay Administration } \\
\text { system }\end{array}$ & 141.6667 & 817.816 & .849 & .953 \\
\hline Product Price & 142.4667 & 831.568 & .704 & .955 \\
\hline Price Perseption & 142.0333 & 823.826 & .841 & .954 \\
\hline $\begin{array}{l}\text { ProductPrice } \\
\text { promotion }\end{array}$ & 141.2667 & 857.306 & .429 & .958 \\
\hline Price competition & 141.9000 & 821.541 & .749 & .954 \\
\hline $\begin{array}{l}\text { Quality of Product } \\
\text { Price }\end{array}$ & 141.7333 & 814.133 & .657 & .956 \\
\hline Transaction safety & 141.7333 & 834.754 & .643 & .956 \\
\hline Situs web safety & 141.6333 & 810.930 & .796 & .954 \\
\hline Service in good situs & 141.6333 & 820.309 & .835 & .953 \\
\hline $\begin{array}{l}\text { Vendor/seller beliefe } \\
\text { in }\end{array}$ & 141.9000 & 811.266 & .652 & .956 \\
\hline Good store & 141.8000 & 818.234 & .796 & .954 \\
\hline $\begin{array}{l}\text { Costomerawarness } \\
\text { insitus online }\end{array}$ & 141.6000 & 822.455 & .856 & .953 \\
\hline $\begin{array}{l}\text { Brand and price } \\
\text { awarnessinsitus online }\end{array}$ & 141.3333 & 833.402 & .808 & .954 \\
\hline $\begin{array}{l}\text { ProductModel always } \\
\text { insitus }\end{array}$ & 141.2000 & 824.579 & .795 & .954 \\
\hline $\begin{array}{l}\text { Customer always buy } \\
\text { product in this situs }\end{array}$ & 141.7333 & 840.823 & .741 & .955 \\
\hline $\begin{array}{l}\text { Customrs want rebuy } \\
\text { product in thissitus }\end{array}$ & 141.5333 & 832.533 & .776 & .954 \\
\hline $\begin{array}{l}\text { Customerplan to buy } \\
\text { other productinsitus } \\
\text { online }\end{array}$ & 141.5000 & 859.845 & .525 & .957 \\
\hline $\begin{array}{l}\text { Customer will buy } \\
\text { same productmore } \\
\text { than before }\end{array}$ & 141.2000 & 826.303 & .752 & .954 \\
\hline
\end{tabular}

Source : Data processed by SPSS 23.00, 2019.

Instrument validity test has the aim of knowing the extent of the accuracy and accuracy of the measuring instrument in carrying out its size function. The calculation is to compare $r$ arithmetic with $r$ tables.Based on Table 5 above, column 4 (Corrected Item-Total Correlation) or $r$ count is compared with the value of $r$ table in the sample of 30 samples. The value of $r$ table is
0.361 . The sum of all the $r$ values above is above the $r$ table, with the conclusion that all the data used in this study are valid.

\subsubsection{Reliability Test}

The reliability test results in this study can be seen based on data processing. 
With the SPSS 23.00 program, as follows:

\begin{tabular}{lr}
\hline $\begin{array}{l}\text { Cronbach's } \\
\text { Alpha }\end{array}$ & N of Items \\
.957 & 22 \\
\hline \multicolumn{2}{c}{ Table 5. Reliability Statistics } \\
processedby SPSS 23.00, 2019
\end{tabular}

Based on table 6 above, the Cronbach's Alpha value is 0.957 . This value has a reliability producing the same data, so that research can be coefficient above 0.6. This means that all indicators of the variables used reliably can be used as a benchmark in measuring consistency in continued.

\subsection{Discussion}

\subsubsection{Goodness of Fit model}

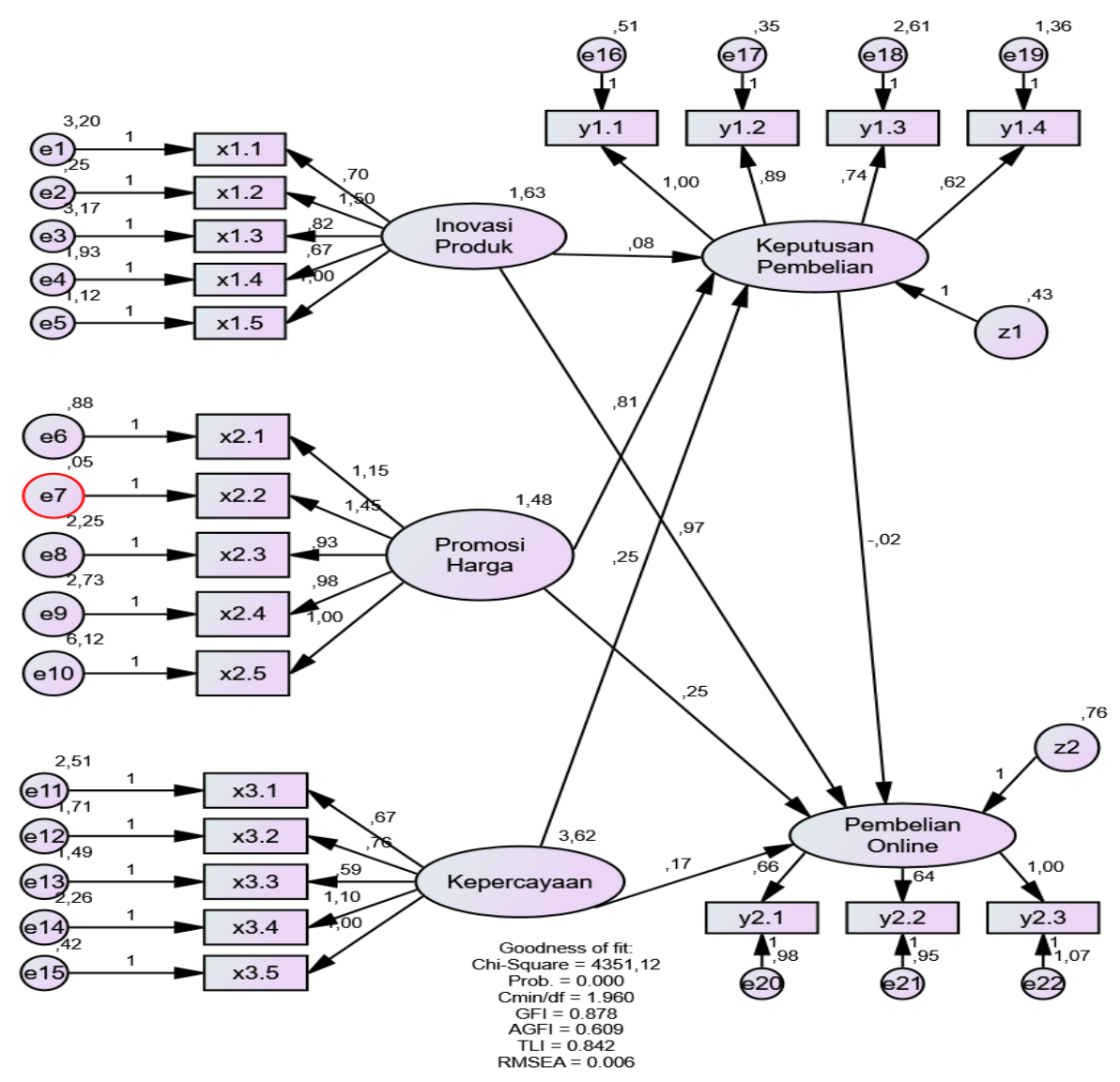

Source : Data processed by SEM AMOS 22.00, 2019

Fig.1. Structural Model

The SEM test results in Figure 1, above show the magnitude of the standard regression coefficient (in SPSS called 'beta' or $\beta$ ), and the squared multiple correlation value (in SPSS known as $\mathrm{R}^{2}$ ). The standard regression coefficient between the price promotion variable and the purchase decision is 0.806 , which means the effect of price promotion on the purchase decision is 0.806 . The value of the standard regression coefficient between the trust variable and the purchase decision is 0.248 , which means the influence of trust on the purchase decision is 0.248 . The value of the standard regression coefficient between product innovation variables with the purchase decision of 1.156, which means the magnitude of the influence of product innovation on the purchase decision of 1.156. The standard regression coefficient between the purchase 
decision variables and online purchases is 0.399 , which means that purchasing decisions do not have the effect of 0.399 on repurchases.

The value of the standard regression coefficient between product innovation variables with repeat online purchases is 0.973 , which means the effect of product innovation on repeat purchases is 0.973 . The value of the standard regression coefficient between the variable price promotion with repeat online purchases is 0.252 , which means that the effect of price promotion on repeat purchases is 0.252 . The standard regression coefficient between the trust variable and online repurchase is 0.168 , which means the magnitude of the effect of trust on repeat online purchases is 0.168 .

Furthermore, the squared multiple correlation $\left(\mathrm{R}^{2}\right)$ value of the purchase decision variable is 0.734 , which means product innovation, price promotion, and trust can only explain the purchase decision of $73.4 \%$. While the value of $\mathrm{R} 2$ on the variable of online repurchase is 0.693 which means product innovation, price promotion, and trust are only able to explain the repurchase online at $69.3 \%$.

\subsubsection{Converting Flow Charts into Equations}

The structural equations produced in this study are as follows:

Table 6. Regression Weights: (Group number 1 - Default model)

\begin{tabular}{|c|c|c|c|c|c|c|}
\hline & & & $\begin{array}{r}\text { Estima } \\
\text { te }\end{array}$ & S.E. & C.R. & $\mathrm{P}$ \\
\hline $\begin{array}{l}\text { Purchase } \\
\text { Decision }\end{array}$ & $<-$ & Price_Promotion & ,806 & , 129 & 6,233 & $* * *$ \\
\hline $\begin{array}{l}\text { Purchase } \\
\text { Decision }\end{array}$ & $<-$ & Trust & ,248 & ,034 & 7,397 & $* * *$ \\
\hline $\begin{array}{l}\text { Purchase } \\
\text { Decision }\end{array}$ & $<-$ & $\begin{array}{l}\text { Product_Inovatio } \\
\mathrm{n}\end{array}$ & ,083 & ,047 & 1,751 &, 080 \\
\hline Purchase_Online & $<--$ & $\begin{array}{l}\text { Purchase } \\
\text { Decision }\end{array}$ &,- 016 & ,161 &,- 098 & ,922 \\
\hline Purchase_Online & $<--$ & $\begin{array}{l}\text { Product_Inovatio } \\
\mathrm{n}\end{array}$ & ,973 & ,097 & $\begin{array}{r}10,05 \\
6\end{array}$ & $* * *$ \\
\hline Purchase_Online & $<--$ & Price_Promotion &, 252 & ,153 & 1,646 &, 100 \\
\hline PurchaseOnline & $<-$ & Trust & 168 & ,063 & 2,682 & 007 \\
\hline
\end{tabular}

Source : Data processed by SEM AMOS 22.00, 2019.

Based on Table 8 above, a hypothesis can be proved as follows:

Purchase Decision $=0.083$ product innovation + 0.806 price promotion +0.249 trust

Repurchase Online $=0.973$ product innovation + 0.252 promotion price +0.168 trust

Purchase Decision $=-0,016$ repeat online purchases

Based on the above equation, the path coefficient is positive so that it will positively influence every change in the exogenous variable ((product innovation, price promotion, trust) in influencing endogenous variables (purchasing decisions). The path coefficient is positive so that it will positively influence every change in the exogenous variable ((product innovation, price promotion, trust) in influencing endogenous variables (repeat online purchases).

\subsubsection{Structural Test Results of The Research Model}

The overall model feasibility test was carried out using SEM with the help of Amos 22.00 software. 
Table 7. Test Results of Goodness-of-Fit Index Struktural Proposed Model

\begin{tabular}{lccc}
\hline $\begin{array}{l}\text { Goodness of Fit Indix } \\
\text { Chi-Square }\left(\chi^{2}\right)\end{array} \quad$ Cutt of Value & Result & Model Evaluation \\
Small expected value & 4351,12 & Good \\
Significance Probability $(p)$ & $\geq 0,05$ & 0.000 & Good \\
CMIN/DF & $\leq 2,00$ & 1.960 & Good \\
GFI & $\geq 0,90$ & 0.905 & Good \\
AGFI & $\geq 0,90$ & 0.609 & Marginal \\
TLI & $\geq 0,95$ & 0.842 & Marginal \\
CFI & $\geq 0,95$ & 0.933 & Good \\
RMSEA & $\leq 0,08$ & 0.006 & Good \\
\hline
\end{tabular}

Source :Primer data processed, 2019.

Based on Figure 1. and table 9, it can be seen that the criteria in the goodness of fit test for the initial structural model still do not meet the recommended critical threshold, there are two criteria that indicate marginal (sufficient) values, namely AGFI, TLI.

\subsubsection{Proof of Hypothesis}

Proving the hypothesis in this study is to look at the causal relationship of each variable forming the model based on 7 hypotheses (H1 to H7). The model assessment is carried out to find out how far the hypothesized model fits or the model is able to explain the existing sample data. Before testing the research hypothesis, testing the instruments forming the research variables is conducted. A contract is said to have a good confirmatory model if it meets the criteria for goodness of fit. In addition, constructs must meet convergent validity and construct reliability. It is said to meet convergent validity if the value of standardized regression weight $>0.5$ and probability is less than $0.05(\alpha=5 \%)$, while the value of reliability construct $\geq 0.7$.

Variables of product innovation, price promotion, trust, purchase decisions and repeat purchases online.

Table 8. Hypotesis test

\begin{tabular}{lllllll}
\hline & & & Estimat & S.E. & C.R. & P \\
& & e & & & \\
$\begin{array}{l}\text { Purchase _ } \\
\text { Decision }\end{array}$ & - & Price_Promotion &, 806 &, 129 & 6,233 & $* * *$ \\
$\begin{array}{l}\text { Purchase__ } \\
\text { Decision }\end{array}$ & $<-$ & Trust &, 248 &, 034 & 7,397 & $* * *$ \\
Purchase _ & - & & & & & \\
Decision & $<-$ & Product_Inovatio &, 083 &, 047 & 1,751 &, 080 \\
Purchase_Online & $<-$ & Purchase_ &,- 016 &, 161 &,- 098 &, 922 \\
& - & Decision & & & & \\
Purchase_Online & $<-$ & Product_Inovatio &, 973 &, 097 & 10,05 & $* * *$ \\
& - & n & & & 6 & \\
Purchase_Online & $<-$ & Price_Promotion &, 252 &, 153 & 1,646 &, 100 \\
& - & & & & & \\
Purchase_Online & $<-$ & Trust &, 168 &, 063 & 2,682 &, 007 \\
& - & & & & & \\
\hline
\end{tabular}

Source :Primer data processed, 2019. 
4.2.4.1. Effect of product innovation on online purchasing decisions

In Table 10 above, it shows that product innovation has a positive but not significant effect on online purchasing decisions. This can be seen in C.R. amounted to 1.751 which fulfilled the requirements namely $<1.96$ with a $\mathrm{p}$ value of 0.080 that met the requirements of $>0.05$. From the above results being a $\mathrm{H} 1$ proofer cannot be accepted.

\subsubsection{Effect of price promotion on online purchasing decisions}

In Table 10 above, it shows that price promotion has a positive effect on online purchasing decisions. The nature of the positive influence is significant, this can be seen in C.R. of 6,233 who met the requirements of $>1.96$ with a $p$ value of 0,000 that met the requirements of $<0.05$. From the above results being a proof of $\mathrm{H} 2$ can be accepted.

\subsubsection{Effect of trust in online purchasing decisions}

In Table 10 above, shows that trust has a positive effect on online purchasing decisions. The nature of the positive influence is significant, this can be seen in C.R. of 7,397 who met the requirements of $>1.96$ with a $p$ value of 0,000 that met the requirements of $<0.05$. From the above results, a proof of $\mathrm{H} 3$ can be accepted.

\subsubsection{Effect of product innovation on repeat online purchases}

In Table 10 above, it shows that product innovation has a positive effect on repeat online purchases. The nature of the positive influence is significant, this can be seen in C.R. amounted to 10,056 that met the requirements of $>1.96$ with a $\mathrm{p}$ value of 0,000 that met the requirements of $<0.05$. From the above results, a proof of $\mathrm{H} 4$ can be accepted.

\subsubsection{Effect of price promotion on repeat online purchases}

Table 10 above shows that price promotion has a positive but not significant effect on repeat online purchases. This can be seen in C.R. amounted to 1.646 which fulfilled the requirements namely $<1.96$ with a $\mathrm{p}$ value of 0.100 that met the requirements of $>0.05$. From the above results being a proof of $\mathrm{H} 5$ is not acceptable.

\subsubsection{Effect of trust on repeat online purchases}

In Table 10 above, it shows that trust has a positive effect on repeat online purchases. The nature of the positive influence is significant, this can be seen in C.R. amounted to 2.682 which fulfilled the requirements $>1.96$ with a $\mathrm{p}$ value of 0.007 which fulfilled the requirements namely $<0.05$. From the above results being a proof of $\mathrm{H} 6$ can be accepted.

\subsubsection{The effect of online purchasing} decisions on online repurchases

This can be seen in C.R. amounting to -0.098 that meets the requirements of $<1.96$ with a $p$ value of 0.922 that meets the requirements of $>$ 0.05 . From the above results being a proof of $\mathrm{H} 7$ is not acceptable.

\section{CONCLUSIONS}

Based on the results and previous discussion, the following conclusions can be drawn:

1. Product innovation has a positive but not significant effect on online purchasing decisions. This means that product innovations carried out as long as the producers/ sellers do not meet the criteria of consumer desires related to lack of design changes.

2. Price promotion has a positive effect on online purchasing decisions. The seller, in this case the vendor, should pay more attention and do updated information related to the price promotion that has been done so far, namely the price of the product must be in accordance with the benefits of the product.

3. Trust has a positive effect on online purchasing decisions. Vendor sellers must further increase the trust of consumers so that it will make consumers still decide to buy their products

4. Product innovation has a positive effect on repeat online purchases. This means that product innovations carried out as long as the producers/ sellers must meet the criteria of 
consumer desires related to the lack of design changes.

5. Price promotion has a positive effect on online purchasing decisions. The seller, in this case the vendor, should pay more attention and do updated information related to the price promotion that has been done so far, namely the price of the product must be in accordance with the benefits of the product.

6. Trust has a positive effect on online purchasing decisions. Vendor sellers must further increase the trust of consumers so that it will make consumers still decide to buy their products. This study has limitations, namely the object of observation conducted in this study is only on consumers/ customers who purchase products online with a total of 200 people, it is recommended that more respondents be added.

Suggestions for future research is to be able to use other variables outside the studied variables in order to obtain more varied results on online repurchases. Future research should look for other additional variables such as customer satisfaction, product availability.

\section{References}

[1] Arul. 2017. Impact of Social Media in Online Shopping. ICTACT Journal On Management Studies, August 2017, Volume: 03, ISSUE: 03. ISSN: 2395-1664 (ONLINE).

[2] Garimaet. al 2015. Impact of Sales Promotion Technique Used by Online Dealers on Consumers. International Journal of Applied Sciences and Management (IJASM).Vol. 1, no.1, 63-78, 2015.ISSN 2413-3396

[3] Zan Mao. 2015. Effect of Online Reviews on Consumer Purchase Behavior. Journal of Service Science and Management, 8, 419424.

http://dx.doi.org/10.4236/jssm.2015.83043

[4] Kotler, Philip dan Gary Amstrong. (2008). Prinsip-Prinsip Pemasaran. Translated by Bob Sabran. MM. Edisi 12. Jakarta:

\section{Erlangga.}

[5] Bayu. 2014. Pengaruh Inovasi Produk dan Harga terhadap Minat Beli Mie Sedaap Cup. Jurnal Ilmu Manajemen | Volume 2 Nomor 4 Oktober 2014.

[6] Harun et al. 2018. Pengaruh Inovasi Produk dan Harga Terhadap Keputusan Pembelian Sepeda Motor Yamaha di Kota Tangerang Selatan. Perspektif Vol. XVI No. 1 Maret 2018.

[7] Achmadet a. 2015. Pengaruh Promosi Online dan Persepsi Hargat erhadap Keputusan Pembelian (Survei Pada Pelanggan Aryka Shop di Kota Malang). Jurnal Administrasi Bisnis (JAB) | Vol. 21 No. 1 April 2015

[8] Samar et al 2017. Inspecting the Role of Intention to Trust and Online Purchase in Developing Countries. Journal of Socialomics. DOI: $10.41 \quad 72 / 2167-$ 0358.1000191

[9] Ratna. 2015. Pengaruh Harga dan Kepercayaan terhadap Keputusan Pembelian secara Online (STUDI KASUS PADA HARAPAN MAULINA HIJAB JOMBANG). EKSIS Volume X No.1, April2015

[10] Wenny. 2015. Analisis Pengaruh Harga dan Kepercayaan Terhadap Minat Beli dan Implikasinya pada Keputusan Pembelian Produk Secara Online Melalui Media Sosial Facebook (Studi Kasus Di Forum Jual-Beli Kota Pangkalpinang.

[11] Marjesi. 2015. Pengaruh Gaya Hidup, Kepercayaan dan Kualitas Informasi Terhadap Keputusan Pembelian Online (StudiKasus : Zalora.Com)

[12] Lily. 2017. What Effects Repurchase Intention of Online Shopping. International Business Research; Vol. 10, No. 12; 2017 ISSN 1913-9004 E-ISSN 1913-9012 Published by Canadian Center of Science and Education.

[13] Ella. 2012. Analisis Faktor-Faktor Kunci Dari Niat Pembelian Secara Online (STUDY KASUSPADA KONSUMEN 
FESH SHOP) Key Factors Analysis of

Online Repurchase (Case Study on

Consumers Shop Fesh). Jurnal Bisnis dan

Ekonomi (JBE), September 2012, Hal. 126

$-$

[14] Ferdinand A., 2014, Metode Penelitian

Manajemen, Edisi 5, Badan Penerbit

Universitas Diponegoro, Semarang

[15] Lin, C., Lekhawipat, W., 2014. Factors affecting online repurchase intention, Industrial Management \& Data Systems, Vol. 114 No. 4, pp. 597611. https://doi.org/10.1108/IMDS-10-20130432 